\title{
PLAUR wt Allele
}

National Cancer Institute

\section{Source}

National Cancer Institute. PLAUR wt Allele. NCI Thesaurus. Code C51718.

Human PLAUR wild-type allele is located within 19q13 and is approximately 24 kb in length. This allele, which encodes urokinase plasminogen activator surface receptor protein, plays a role in the regulation of both cell-surface plasminogen activation and localized degradation of the extracellular matrix. 